Jackson, C. M. (1925). The Effects of Inanition and Malnutrition upon Growth and Structure. London: J. and A. Churchill.

Krause, A. C. (I934). The Biochemistry of the Eye. Baltimore: Johns Hopkins Press.

Lafon, M. (1939). Ann. Physiol. Physicochim. biol. 15, I.

Limson, M. \& Jackson, C. M. (1932). F. Nutr. 5, I63.

Lowrey, L. G. (1913). Anat. Rec. 7, 143.

Platt, B. S. \& Miller, P. J. (1957). Proc. Nutr. Soc. 16, ix.

\title{
The influence of alternate high-protein and low-protein feeding on growth and reproduction and on regeneration of haemoglobin in rats
}

\author{
BY ANNA W. I. vAN DAM-BAKKER, A. P. DE GROOT AND R. LUYKEN \\ Central Institute for Nutrition Research T.N.O., Utrecht, The Netherlands \\ (Received 8 Fanuary 1958-Rerised I7 March I958)
}

In some tropical areas nutrition is characterized by an irregular protein intake, meals containing little or no protein alternating with meals very rich in proteins. Such a food habit was observed by Luyken \& Luyken-Koning (1955) in the south of Netherlands New Guinea, where the protein intake is temporarily very high after a day of hunting or fishing, but afterwards almost only carbohydrates (in the form of sago) are consumed for days on end.

Animal experiments have shown that a diet is not optimal when the protein fraction is given separate in time from the rest of the diet. Cuthbertson, McCutcheon \& Munro (1940) observed that in adult rats, which in the morning were fed on a proteinfree meal followed by a given amount of protein in the afternoon, the nitrogen retention was lower than when both fractions were administered as a mixture, and Geiger (1948b) showed that the growth of rats, which overnight had a protein-free ration, but during $2 \mathrm{~h}$ of the day could eat so much of a protein mixture that the total diet contained $20 \%$ protein, was less than that of control rats which received the same quantities of food as a mixture.

Animal experiments have likewise demonstrated that two deficient proteins, which in combination form a good protein mixture (e.g. yeast protein and wheat gluten), do not supplement each other when they are given with an interval (Geiger, I948 $a$; Henry $\&$ Kon, $1945^{-6)}$. This effect appeared also from alternate administration of a deficient protein and the lacking amino-acid (Geiger, 1947). All these experiments were continued for only a short time. It seemed of importance to us to study the influence of alternate feeding of a high-protein and a low-protein ration to rats over a longer period of observation. In these experiments we determined growth rate, fertility, haemoglobin content and recovery of the haemoglobin level after experimentally induced anaemia.

The anaemia served as a stress factor to make the experiment more readily comparable with the human conditions to which we wish to relate the experimental results. 
Laboratory animals are usually kept under optimal conditions, whereas man is often exposed to stress, e.g. from work, cold, hunger, or infectious diseases. The stress factor chosen in the experiment was anaemia, because it occurs frequently in areas where the protein intake is intermittent, for example, among the Papuans of southern New Guinea, where it is due among other things to malaria. Moreover, the rapidity with which the haemoglobin content recovers is influenced by the quality of the protein in the diet (Orten \& Orten, 1946; Mahalanobis \& Roy, 1952) and it may also be influenced by the pattern of consumption of protein, i.e. whether intermittent or continuous.

\section{METHODS}

Experimental animals. The experiment was begun with forty-eight newly weaned albino rats from our laboratory colony, divided into two groups of twenty-four animals each (twelve males and twelve females). One group (the experimental group) was given alternately the high-protein moiety and the low-protein moiety of a diet, while the other group (the control group) was given both moieties mixed. Hereditary differences between the groups were avoided as far as possible by litter-mate distribution of the experimental animals.

Housing. The animals were placed in four groups in wire cages (twelve rats in each cage), provided with a wire bottom to prevent coprophagy. The cages were arranged in a large room, well ventilated and kept at a constant temperature (about $24^{\circ}$ ).

Feeding. The diet was composed of a high-protein fraction ( $70 \%$ crude protein) and a low-protein fraction which contained all other necessary nutrients, but only $2 \%$ crude protein. The high-protein fraction consisted of equal parts of commercial fish meal and potato protein (a by-product of the potato-starch industry with $70 \%$ crude protein, whose nutritive value was found to be somewhat less than that of casein). The low-protein fraction was composed as follows: wheat starch $54^{\cdot 1}$, soya-bean oil 4 , Steenbock's mineral mixture no. 40 (Steenbock \& Nelson, I923) 4, precipitated chalk I, $\mathrm{NaCl} 0.5$, an oily solution of vitamins $\mathrm{A}, \mathrm{D}_{2}$ and $\mathrm{E}$ (containing 2000 i.u. vitamin $\mathrm{A}$, 500 i.u. ergocalciferol and 5 i.u. DL- $\alpha$-tocopheryl acetate/g groundnut oil) 0.4 , Vital (a vitamin concentrate containing $(\mathrm{mg} / \mathrm{kg})$ thiamine 40 , riboflavin 100, nicotinic acid 400 , pantothenic acid I70, pyridoxine 10, choline chloride 3000 , carotene 3 and vitamin $\mathrm{E}$ I00) 3 , and brewer's yeast 3 parts.

The experimental group was fed alternately on the high-protein and the lowprotein fraction, whereas the control group was given a combination of both fractions in the ratio $3: 7$. The protein content of the combined fractions was $22.4 \%$.

The experimental group was fed ad lib. on the low-protein fraction and the amount consumed was determined. For the following feeding period this group was given three-sevenths of this amount in the form of the high-protein fraction. The control group received at each feeding the same quantity of the combined diet (i.e. 3 parts of the high-protein diet mixed with 7 parts of the low-protein diet) as the test group had consumed in the previous period. In this way the group given protein intermittently had eaten, after two consecutive feeding periods, just the same quantity of food of the same composition as the control group had consumed in the form of the combined diet. 
Only during the first 6 weeks of the experiment were the groups fed twice daily (at $09.00 \mathrm{~h}$ and $\mathrm{I} 7.00 \mathrm{~h}$ ), the experimental group receiving protein-rich food during the day and protein-deficient food during the night. Subsequently the food was changed only once every $24 \mathrm{~h}$ (at $09.00 \mathrm{~h}$ ).

Since the amount of protein-rich food was restricted the animals fasted for some hours before feeding on the protein-deficient fraction. The control animals with the higher appetite fasted for some hours before each feeding.

Scattering of food was almost completely prevented by adding enough water to make it into a thin paste.

Pregnant females were caged individually from several days before parturition until weaning of the young. During this period all mothers received equal quantities of the diet, and the food was consumed completely by nearly all animals. The protein-rich and protein-low diets were given, however, in such quantities $(3: 7)$ that the experimental and the control animals had consumed equal quantities of nutrients after 2 days.

Weighing. During the first 2 months of the growth experiments the animals were weighed individually once a week, at a fixed hour, then at longer intervals. The mothers and the litters were weighed within $24 \mathrm{~h}$ after parturition and then at weekly intervals for 4 or 5 weeks.

Reproduction and lactation. Fertility was studied by determination of the percentage of females in the experimental and control groups which, after brother-sister mating within the group, had produced a litter. The mothers and the litters were weighed directly after birth, and the number of young counted. The litters were made equal within 3 days after birth (after the first two litterings ten and subsequently eight young/litter) and the growth during the lactation period was determined by weighing of mothers and young at weekly intervals. Owing to the retarded growth the young were not weaned until 4 or 5 weeks of age, which is about I or 2 weeks later than normal.

Haemoglobin content. Haemoglobin was determined by means of the alkalinehaematin method in a Coleman Jr. spectrophotometer. A standard curve was prepared from blood with known haemoglobin percentage, calculated from the iron content.

Production of anaemia. Adult male albino rats raised on a normal stock ration received for 4 weeks the experimental diets, one group being given the high-protein and the low-protein fractions on alternate days and the second group both moieties together. Experimental anaemia was then produced by intraperitoneal injection of I $50 \mathrm{mg}$ phenylhydrazine/ $\mathrm{kg}$ body-weight distributed over 3 consecutive days (Hahn, Bale, Hettig, Kamen \& Whipple, I939).

\section{RESULTS}

\section{Growth}

Table I summarizes the mean increases in weight, obtained on intermittent and combined (normal) protein feeding of the animals with which the experiment was begun (parent generation). Table 2 gives the same information for the young obtained from 
the first mating of the parent generation. These figures show that rats fed alternately on a high-protein and a low-protein diet grew more slowly than litter-mate control animals which ate the same quantity of food of the same composition, but in which the protein was combined with the other dietary components. The difference in growth rate, which was manifest from the very beginning of the experiment, caused in males as well as in females considerable weight differences in favour of the animals fed normally.

Table I. Mean gain in weight of male and female rats (parent generation) on intermittent and normal protein feeding

\begin{tabular}{|c|c|c|c|c|c|c|c|c|c|c|c|c|c|c|}
\hline \multirow[b]{2}{*}{$\begin{array}{l}\text { Type of } \\
\text { feeding }\end{array}$} & \multirow[b]{2}{*}{$\begin{array}{l}\text { No. of } \\
\text { animals }\end{array}$} & \multirow{2}{*}{$\begin{array}{c}\text { Initial } \\
\text { weight } \\
\text { (g) }\end{array}$} & \multicolumn{12}{|c|}{ Gain in weight (g) after } \\
\hline & & & $\begin{array}{c}7 \\
\text { days }\end{array}$ & $\begin{array}{c}\text { I4 } \\
\text { days }\end{array}$ & $\begin{array}{c}2 \mathrm{I} \\
\text { days }\end{array}$ & $\begin{array}{l}28 \\
\text { days }\end{array}$ & $\begin{array}{r}35 \\
\text { days }\end{array}$ & $\begin{array}{c}42 \\
\text { days }\end{array}$ & $\begin{array}{c}49 \\
\text { days }\end{array}$ & $\begin{array}{r}56 \\
\text { days }\end{array}$ & $\begin{array}{r}70 \\
\text { days }\end{array}$ & $\begin{array}{r}84 \\
\text { days }\end{array}$ & $\begin{array}{c}\text { I6r } \\
\text { days }\end{array}$ & $\begin{array}{l}284 \\
\text { days }\end{array}$ \\
\hline \multicolumn{15}{|c|}{ Males } \\
\hline Intermittent & I 2 & 49 & ro & 26 & $5 \mathrm{x}$ & 76 & I IO & 129 & I 41 & r 53 & 189 & 201 & 292 & $33^{2}$ \\
\hline Normal & I 2 & 49 & 15 & 35 & 65 & 92 & 130 & 160 & 165 & 192 & 229 & 259 & 349 & 403 \\
\hline \multicolumn{15}{|c|}{ Females } \\
\hline Intermittent & 12 & 46 & 9 & 22 & 43 & 63 & 86 & 100 & Io8 & 114 & 128 & 146 & 176 & \\
\hline Normal & 12 & 46 & 13 & $3 I$ & 58 & 80 & 103 & I I 8 & 126 & 140 & $\times 55$ & 174 & 215 & \\
\hline
\end{tabular}

Table 2. Mean gain in weight of male and female rats (first generation) on intermittent and normal protein feeding

\begin{tabular}{|c|c|c|c|c|c|c|c|c|c|c|c|c|c|}
\hline \multirow[b]{2}{*}{$\begin{array}{l}\text { Type of } \\
\text { feeding }\end{array}$} & \multirow[b]{2}{*}{$\begin{array}{c}\text { No. of } \\
\text { animals }\end{array}$} & \multirow[b]{2}{*}{$\begin{array}{l}\text { Initial } \\
\text { weight } \\
\text { (g) }\end{array}$} & \multicolumn{11}{|c|}{ Gain in weight $(\mathrm{g})$ after } \\
\hline & & & $\begin{array}{c}7 \\
\text { days }\end{array}$ & $\begin{array}{c}14 \\
\text { days }\end{array}$ & $\begin{array}{l}21 \\
\text { days }\end{array}$ & $\begin{array}{c}28 \\
\text { days }\end{array}$ & $\begin{array}{l}35 \\
\text { days }\end{array}$ & $\begin{array}{l}42 \\
\text { days }\end{array}$ & $\begin{array}{c}49 \\
\text { days }\end{array}$ & $\begin{array}{c}5^{6} \\
\text { days }\end{array}$ & $\begin{array}{c}70 \\
\text { days }\end{array}$ & $\begin{array}{c}84 \\
\text { days }\end{array}$ & $\begin{array}{l}\text { I } 59 \\
\text { days }\end{array}$ \\
\hline \multicolumn{14}{|c|}{ Males } \\
\hline Intermittent & I 2 & 22 & 12 & 17 & 27 & $3^{6}$ & 52 & 63 & $8 \mathrm{r}$ & 93 & 116 & 148 & 229 \\
\hline Normal & I 2 & 30 & 24 & 39 & 42 & 58 & 74 & 96 & I IO & 143 & I 55 & I 85 & 273 \\
\hline \multicolumn{14}{|c|}{ Females } \\
\hline Intermittent & I 2 & 23 & 9 & 14 & 23 & 28 & 42 & 52 & 69 & 78 & 94 & I 4 & \\
\hline Normal & 12 & 29 & 22 & 36 & 39 & $5^{I}$ & 62 & 83 & 96 & I 5 & 127 & 146 & \\
\hline
\end{tabular}

The lag was apparently not made up, for even when the growth experiments ended (after 9 and 5 months for the parent generation and the first generation, respectively) the differences were still considerable. It should be pointed out that the differences arose in spite of equal food consumption by both groups, the group fed normally receiving no more food than the group given protein intermittently. The appetite of the former group was, however, considerably better than that of the latter, which leads to the assumption that the differences would have been even greater with ad lib. feeding. When the values in Tables $I$ and 2 are compared, it will be noticed that the weights found in the second experiment were considerably lower than those at the same ages in the first experiment. This difference has probably to be attributed to the general undernutrition of the animals of the first generation while they were nursed by the mothers, because supplementary experiments have shown that undernutrition during the suckling period causes slower growth after weaning as well as lower adult weight. 


\section{Reproduction}

The results of three consecutive matings of the parent generation and of two matings of the first generation are listed in Table 3. There was no difference of any significance between the number of litters in each group. Over five matings, $95 \%$ of the females in the experimental group produced a litter, as against $97 \%$ in the control group.

The total number of young/group, however, was for all five matings somewhat smaller in the test group than in the control group. The number of young/litter, the birth weight of the young and their mortality did not show consistent differences.

Table 3. Mean values for reproductive performance of female rats on intermittent $(I)$ and normal $(N)$ protein feeding in two successive generations

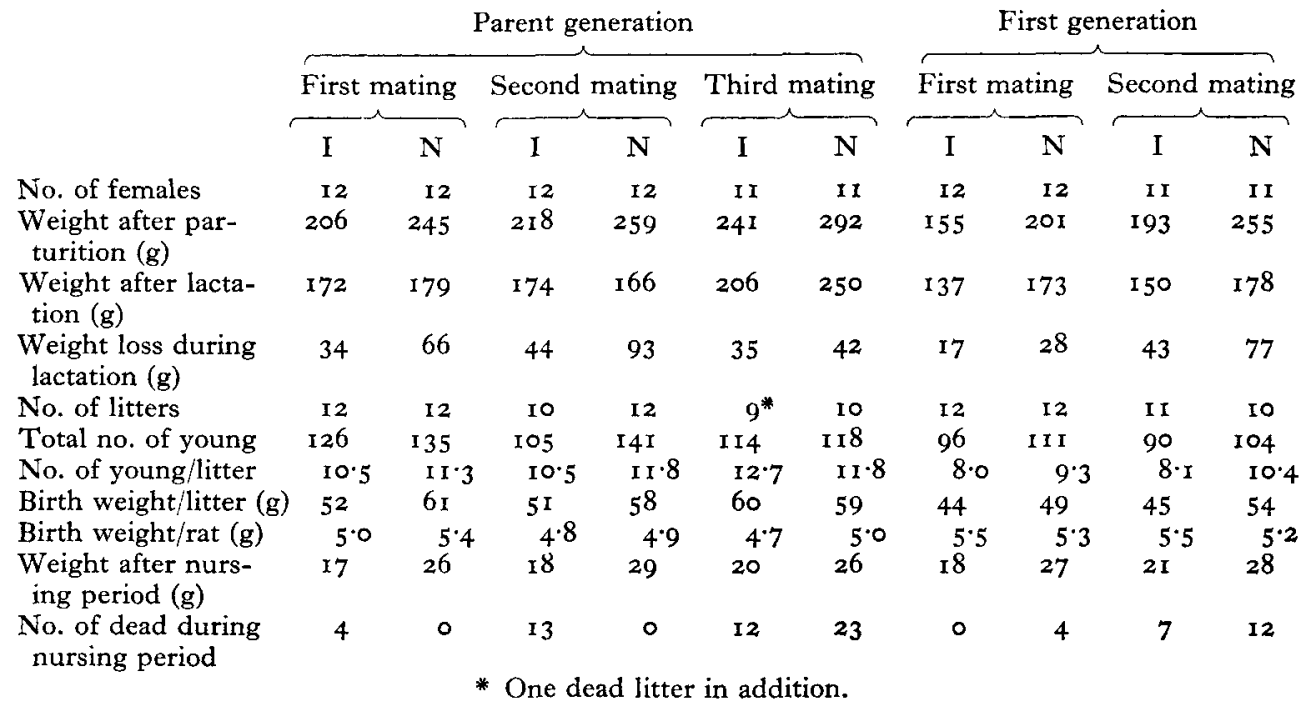

There was a very clear difference in growth between the young of the two groups in the nursing period. The young of the mothers given protein intermittently gained in each of the five nursing periods considerably less than did those of the mothers on the combined diet. This difference was paralleled by smaller loss of weight of the lactating mothers in the experimental group. The unsatisfactory growth of the young and the smaller weight loss of the mothers point to a decreased lactational capacity. That the cause of these differences is indeed to be sought in the mothers and not in the young themselves, was demonstrated by letting a mother from the normal group nurse newborn rats from the experimental group, and conversely. The sucklings from the test group then gained like those of mothers on the normal diet, and conversely.

The less satisfactory nutritional condition of the young of the mothers given protein intermittently became clearly manifest after weaning, when young of both groups were raised on a normal stock ration. The mean increases in weight are shown in Table 4 . The offspring of the experimental group gained less on a stock ration than did the offspring of the control group. The difference in weight increased further as the young 
became older. After 5 months on the stock ration this difference was 12 and $\mathrm{II} \%$, respectively, for males and females of the first generation, which demonstrates a clear after-effect of the intermittent protein feeding of the mothers during the lactation period.

The reproduction experiments indicated that fertility is not noticeably influenced by intermittent protein feeding, but that the lactation capacity of the mothers suffers considerably.

Table 4. Mean gain in weight on stock ration of weanling rats, from parents on intermittent and normal protein feeding

\begin{tabular}{|c|c|c|c|c|c|c|c|c|c|c|c|c|c|c|}
\hline \multirow[b]{2}{*}{$\begin{array}{l}\text { Type of } \\
\text { feeding of } \\
\text { parents }\end{array}$} & \multirow[b]{2}{*}{$\begin{array}{l}\text { No. of } \\
\text { animals }\end{array}$} & \multirow[b]{2}{*}{$\begin{array}{l}\text { Initial } \\
\text { weight } \\
\text { (g) }\end{array}$} & \multicolumn{12}{|c|}{ Gain in weight (g) after } \\
\hline & & & $\begin{array}{c}7 \\
\text { days }\end{array}$ & $\begin{array}{c}\text { I4 } \\
\text { days }\end{array}$ & $\begin{array}{c}2 \mathrm{I} \\
\text { days }\end{array}$ & $\begin{array}{c}28 \\
\text { days }\end{array}$ & $\begin{array}{r}35 \\
\text { days }\end{array}$ & $\begin{array}{c}4^{2} \\
\text { days }\end{array}$ & $\begin{array}{r}49 \\
\text { days }\end{array}$ & $\begin{array}{r}5^{6} \\
\text { days }\end{array}$ & $\begin{array}{r}70 \\
\text { days }\end{array}$ & $\begin{array}{c}84 \\
\text { days }\end{array}$ & $\begin{array}{c}\text { I } 54 \\
\text { days }\end{array}$ & $\begin{array}{c}371 \\
\text { days }\end{array}$ \\
\hline \multicolumn{15}{|c|}{ Males } \\
\hline Intermittent & 12 & 22 & 14 & 29 & 48 & $5^{8}$ & 88 & I I 7 & 139 & 156 & I 83 & 201 & 269 & - \\
\hline Normal & 12 & $3 \mathrm{I}$ & 20 & 37 & $5^{8}$ & 76 & 108 & I 39 & 158 & 171 & $2 \times 2$ & 235 & 307 & 一 \\
\hline \multicolumn{15}{|c|}{ Females } \\
\hline Intermittent & I 2 & 23 & 17 & 42 & 53 & 58 & 78 & 97 & 110 & I 18 & I34 & I 43 & 164 & 249 \\
\hline Normal & 12 & 29 & 19 & $4 I$ & $6 I$ & 77 & 98 & IIO & 122 & 132 & 148 & $15 \mathrm{I}$ & 185 & 279 \\
\hline
\end{tabular}

\section{Haemoglobin content}

The haemoglobin content of adult males and of sucklings was not noticeably affected by the manner of feeding. Haemoglobin values of adult female rats showed a significant difference shortly after the lactation period, with mean values of $\mathrm{I2} \cdot \mathrm{I}$ and $\mathrm{I} 3.8 \mathrm{~g}$ $\mathrm{Hb} /$ Ioo ml. blood for the experimental and the control group, respectively. The standard error of the difference was 0.25 . Some weeks after weaning no such difference was found; the values were then 12.9 and $\mathrm{I} 3.4 \mathrm{~g} \mathrm{Hb} / \mathrm{IOO} \mathrm{ml}$. blood, respectively, with a standard error of the difference of 0.50 .

\section{Haemoglobin content after phenylhydrazine administration}

Table 5 shows that the recovery of the haemoglobin content, after development of a severe anaemia (a decrease of haemoglobin from 14.0 to $4.5 \mathrm{~g} / 100 \mathrm{ml}$.), took more time in the animals given protein intermittently than in those fed in the normal way. The differences were significant $(P<0.05)$ on the 9 th, IIth, I 3 th and 19 th day after the beginning of the experiment. Repetition of this experiment (second part of Table 5) confirmed these findings with significant differences $(P<0.05)$ on the 7 th, 9 th, 16 th, rgth, 26th and 29th day.

\section{DISCUSSION}

The results show that the animals given the high-protein and the low-protein moiety of the ration alternately were, in various respects, in a less favourable condition than those given both moieties simultaneously. Growth, and particularly lactation, were harmfully influenced. Even when the young, after weaning, were placed on a normal stock ration, the difference in weight persisted during the rest of their youth. Haemoglobin 
formation was also slightly disturbed in the animals given protein every and day. During recovery from severe anaemia, produced by administering phenylhydrazine, the haemoglobin content was always somewhat less in the group given protein intermittently than in the group on a normal diet.

It might be of interest to study the influence of intermittent protein feeding in experimental animals exposed to harmful influence like those enumerated on p. 260.

Table 5. Mean haemoglobin content of the blood of rats on intermittent and normal protein feeding, after phenylhydrazine administration

\begin{tabular}{|c|c|c|c|c|}
\hline \multirow{2}{*}{$\begin{array}{l}\text { Days after } \\
\text { first ad- } \\
\text { ministration }\end{array}$} & \multirow{2}{*}{$\begin{array}{l}\text { Phenyl- } \\
\text { hydrazine } \\
(\mathrm{mg} / \mathrm{kg})\end{array}$} & \multicolumn{2}{|c|}{ Haemoglobin ( $\mathrm{g} / \mathrm{I} 00 \mathrm{ml})}$. & \multirow{2}{*}{$\begin{array}{l}\text { Difference of the } \\
\text { means with } \\
\text { standard error } \\
\text { of difference }\end{array}$} \\
\hline & & $\begin{array}{l}\text { Intermittent } \\
\text { feeding }\end{array}$ & $\begin{array}{l}\text { Normal } \\
\text { feeding }\end{array}$ & \\
\hline \multicolumn{5}{|c|}{ First series } \\
\hline 0 & 60 & $14.4(12)$ & $13 \cdot 7(12)$ & \\
\hline I & 60 & & & \\
\hline 2 & 30 & & & \\
\hline 4 & 0 & $4.8(9)$ & $4 \cdot 5(8)$ & \\
\hline 5 & 0 & $6 \cdot 2(9)$ & $6 \cdot 2(8)$ & \\
\hline 6 & $\circ$ & $7 \cdot 7(9)$ & $8 \cdot 1(8)$ & $0.40 \pm 0.50$ \\
\hline 7 & $\circ$ & $9 \cdot 5(9)$ & $9 \cdot 9(8)$ & $0.40 \pm 0.56$ \\
\hline 8 & $\circ$ & $10.7(9)$ & II $3(8)$ & $0.59 \pm 0.50$ \\
\hline 9 & 0 & I I · $2(9)$ & $12 \cdot 5(8)$ & $\mathrm{r} \cdot 22 \pm 0.52^{*}$ \\
\hline II & $\circ$ & $12 \cdot 4(9)$ & $13.7(8)$ & $I .30 \pm 0.5 I^{*}$ \\
\hline I3 & 0 & I $2 \cdot 6(9)$ & $14^{\prime 2}(8)$ & $I \cdot 67 \pm 0 \cdot 3^{6 * *}$ \\
\hline I 5 & 0 & I3.9 (9) & $14 \cdot 2(8)$ & $0.34 \pm 0.27$ \\
\hline I9 & 0 & I 3.8 (9) & $14 \cdot 7(8)$ & $0.90 \pm 0.3 I^{*}$ \\
\hline \multicolumn{5}{|c|}{ Second series } \\
\hline 0 & 60 & & & \\
\hline I & 60 & & & \\
\hline 2 & 30 & & & \\
\hline 4 & 0 & $5 \cdot 6(5)$ & $6 \cdot 2$ (10) & $0.54 \pm 0.28$ \\
\hline 7 & 0 & $9 \cdot x(5)$ & $10.6(10)$ & $\mathrm{I} .5 \mathrm{I} \pm 0.63^{*}$ \\
\hline 9 & 0 & II $6(7)$ & I 3.6 (I I) & $I .91 \pm 0.57 * *$ \\
\hline I 2 & 0 & $I 4 \cdot I(6)$ & 14.8 (II) & $0.76 \pm 0.40$ \\
\hline I6 & $\circ$ & 1 $3.6(7)$ & $14.8(9)$ & $I \cdot I 8 \pm 0.27 * *$ \\
\hline 19 & o & I $3.9(7)$ & $15 \cdot 4(9)$ & $I \cdot 50 \pm 0.26^{* *}$ \\
\hline 26 & 0 & $15.6(7)$ & $16 \cdot I$ (II) & $0.49 \pm 0.22 *$ \\
\hline 29 & 0 & $15.7(6)$ & $16.9(\mathrm{Ir})$ & $I \cdot 17 \pm 0.46^{*}$ \\
\hline $3^{6}$ & 0 & $16 \cdot 3(7)$ & 16.1 (II) & \\
\hline
\end{tabular}

Figures in parentheses show the number of animals.

* Significant at the $5 \%$ level. $\quad * *$ Significant at the I \% level.

\section{SUMMARY}

1. Forty-eight newly weaned albino rats were divided into two groups each containing twelve males and twelve females. One group was given a high-protein and a low-protein diet on alternate days; the other group was given every day the two diets mixed in such quantity and proportions that after 2 days both groups had consumed the same quantity of food of the same composition.

2. Growth, reproduction, lactational performance and recovery of blood haemoglobin after anaemia produced by injection of phenylhydrazine were studied in the two groups, and the observations were extended to the following generation. 
3. The growth rate of young rats, given the high-protein and the low-protein moieties of the diet on alternate days was less than that of pair-fed, litter-mate control animals consuming both moieties together.

4. Intermittent protein feeding likewise impaired lactational capacity of the mothers and retarded recovery of the haemoglobin content of the blood after experimentally induced anaemia.

5. Fertility was not noticeably affected by intermittent feeding of protein.

6. The less satisfactory condition of the young of the mothers given protein intermittently remained clearly manifest after weaning, when young of both groups were raised on a normal stock diet.

\title{
REFERENCES
}

Cuthbertson, D. P., McCutcheon, A. \& Munro, H. N. (1940). Biochem. F. 34, 1002.

Geiger, E. (r947). F. Nutr. 34, 97.

Geiger, E. (1948a). F. Nutr. 36, 81 3.

Geiger, E. (1948b). Science, 108, 42.

Hahn, P. F., Bale, W. F., Hettig, R. A., Kamen, M. D. \& Whipple, G. H. (1939). F. exp. Med. 70, 443. Henry, K. M. \& Kon, S. K. (1945-6). F. Dairy Res. 14, 330.

Luyken, R. \& Luyken-Koning, F. W. M. (1955). Docum. Med. geogr. trop. 7, 315.

Mahalanobis, S. K. \& Roy, R. N. (1952). Indian F. Physiol. allied Sci. 6, I20.

Orten, J. M. \& Orten, A. U. (1946). F. Nutr. 3I, 765.

Steenbock, H. \& Nelson, E. M. (1923). F. biol. Chem. 56, 355 .

\section{Excretion of chromium sesquioxide and polyethyleneglycol by dairy cows}

\author{
By J. L. CORBETT, J. F. D. GREENHALGH, P. E. GWYNN \\ AND D. WALKER \\ Rowett Research Institute, Bucksburn, Aberdeenshire
}

(Received I 3 Fanuary 1958)

The concentration of the inert feed-marker chromium sesquioxide $\left(\mathrm{Cr}_{2} \mathrm{O}_{3}\right)$ in the faeces of cattle and sheep normally varies considerably during the course of $24 \mathrm{~h}$, although it had been administered regularly for long periods mixed with the concentrates fed to the animals as a part of their ration (Kane, Jacobson \& Moore, 1952; Bloom, Jacobson, Allen, McGilliard \& Homeyer, 1957) or in gelatin capsules (Hardison \& Reid, 1953; Hardison, Engel, Linkous, Sweeney \& Graf, 1956; Pigden \& Brisson, I956; Raymond \& Minson, I955). In consequence estimates of food digestibility or of faeces output derived from the concentration of $\mathrm{Cr}_{2} \mathrm{O}_{3}$ in a single defaecation may be erroneous.

Sperber, Hydén \& Ekman (I953) suggested that a polyethyleneglycol (PEG) of high molecular weight (4000) could be used for tracing the flow of water and solutes from the reticulo-rumen into the omasum, and this technique has been used by Oyaert (1955). 